\title{
\begin{tabular}{l|l|l} 
& Jurnal Kependidikan Dasar & Volume : \\
& Nomor :2 \\
Islam Berbasis Sains & Tahun :2018
\end{tabular}
}

\section{Nilai-nilai Karakter dalam Novel Hafalan Sholat Delisa}

\author{
Dwi Masdi Widada \\ Dosen Universitas Islam Negeri Malang \\ Surel : widoke_11@yahoo.co.id
}

\begin{abstract}
Abstrak
Penelitian ini merupakan jenis penelitian kualitatif deskriptif dengan pendekatan nilai-nilai pendidikan budaya karakter bangsa. Teknik pengumpulan data menggunaka metode dokumentasi dan metode telaah teks. Metode dokumentasi dilaksanakan untuk mengumpulkan, memilah, mengolah, dan menyampaikan informasi untuk dapat mengkaji data selanjutnya.Analisis data dilakukan secara analisis isi. validitas data yang digunakan menggunakan trianggulasi data untuk mengumpulkan data yang sama. Artinya data yang sama atau sejenis akan lebih mantap kebenaranya bila digali dari beberapa sumber data yang berbeda. Novel HSD ditinjau dari strukturnya menceritakan kehidupan seseorang dari awal sampai meninggal, tema dalam novel ini banyak mengangkat tentang tema motivasi pendidikan dn hidup, rasa kemanuasiaan yang terekam sikap rasa simpati dan empati terhadap sesama. Peristiwa dalam novel ini terjadi di LhokNga dengan alur yang digunakan dalam novel maju. Amanat dalam novel ini adalah pentingnya hafalan bacaan shalat, sikap sabar dalam menghadapi cobaan apa pun, selalu bersyukur kepada Tuhan dalam keadaan suka dan duka. Kebutuhan aktualisasi diri dalam novel ditunjukkan adanya keinginan dalam diri tokoh untuk selalu mengaktualisasikan setiap citacita dan keinginannya untuk menghafalkan bacaan shalat dengan sempurna. Novel HSD sarat akan nilai pendidikan untuk pembacanya, terdiri dari nilai pendidikan agama yang menjelaskan hubungan manusia dengan Tuhannya, nilai moral yang mengatur baik buruknya perilaku manusia dalam hubungannya dengan sesama, nilai pendidikan sosial yang menunjukkan rasa peduli antar manusia satu dengan yang lain sesuai peranannya sebagai makhluk sosial; dan nilai pendidikan budaya bangsa yang menunjukkan kebiasaan dan cara pandang masyarakat dalam menjalani kehidupan.
\end{abstract}

Kata kunci : nilai karakter, pendidikan berbudaya, dan toleransi 


\begin{abstract}
This research is a descriptive qualitative research with approach of cultural character education. Technique of collecting data using method of documentation and method of study of text. Documentation method is carried out to collect, sort, process, and convey information to be able to review the next data. Data analysis is done by content analysis. the validity of data used using triangulation of data to collect the same data. This means that the same or similar data will be more steady kebenaranya when extracted from several different data sources. HSD novel in terms of its structure tells the life of a person from the beginning to death, the theme in this novel is much raised about the theme of educational motivation and life, a sense of kemanuasiaan recorded the attitude of sympathy and empathy towards each other. The events in this novel occur in LhokNga with the grooves used in the advanced novel. The mandate of this novel is the importance of rote recitation, patience in the face of any trials, always thanking God in circumstances of joy and sorrow. The need for self-actualization in the novel shows the desire in the character to always actualize every aspiration and desire to memorize the prayer read perfectly. The novel HSD is full of educational value for its readers, consisting of religious education value that explains the human relationship with God, the moral values that regulate the good of human behavior in relation to others, the value of social education that shows the caring of human beings with each other according to its role as social beings; and the value of the nation's cultural education that demonstrates the habits and perspectives of people in living their lives.
\end{abstract}

Keywords: character values, cultured education, and tolerance

\section{A. PENDHULUAN}

Gejala kemerosotan moral dewasa ini sudah benar-benar mengkhawatirkan. Kejujuran, keadilan, sikap tolongmenolong dan kasih sayang sudah tertutup oleh penyelewengan, penipuan, penindasan, saling menjegal dan saling merugikan. Kemerosotan nilai-nilai semacam ini merupakan kemerosotan mental yang sudah mengagar jauh-jauh hari. Banyak terjadi adu domba dan fitnah, menjilat, menipu, mengambil hak orang lain sesuka hati dan perbuatan-perbuatan maksiat lainnya. Kemerosotan moral yang demikian itu lebih mengkhawatirkan lagi karena bukan hanya menimpa kalangan orang dewasa dalam berbagai jabatan, kedudukan dan profesinya, melainkan juga telah menimpa kepada pelajar tunastunas muda yang diharapkan dapat melanjutkan perjuangan membela kebenaran, keadilan dan perdamaian masa depan.

Pendidikan budaya dan karakter bangsa dimaknai sebagai pendidikan yang mengembangkan nilai-nilai budaya dan karakter bangsa pada diri dan peserta didik sehingga mereka memiliki nilai dan karekter dirinya, menerapkan nilai-nilai tersebut dalam kehidupan dirinya sebagai 
anggota masyarakat dan warganegara yang religius, nasionalis, produktif dan kreatif ${ }^{1}$. Berdasarkan pengertian di atas bahwa karakter adalah kualitas kekuatan mental atau moral, akhlak atau budi pekerti individu yang mempunyai kepribadian khusus sehingga berbeda dengan individu-individu lain. Pendidikan karakter lebih mengutamakan pertumbuhan moral individu yang ada dalam lembaga pendidikan dengan memperlihatkan jati diri yang bermoral.

Belakangan ini kita banyak mendengar keluhan orang tua, ahli pendidik dan orang-orang yang berkecimpung dalam bidang agama dan sosial, berkenaan dengan ulah perilaku remaja yang sukar dikendalikan, nakal, keras kepala, berbuat keonaran, maksiat, tawuran, mabuk-mabukan, pesta obatobat terlarang. Nilai-nilai budaya maasih belum tertanam. Bahkan melakukan pembajakan, pemerkosaan pembunuhan dan penyimpangan tingkah laku lainnya. Tingkah laku penyimpangan yang ditunjukan oleh sebagian generasi muda harapan masa depan bangsa itu sungguhpun jumlahnya mungkin hanya sepersekian persen dari jumlah pelajar secara keseluruhan. Sungguh amat disayangkan kredibilitas dunia pendidikan mulai tercoreng. Semua penyimpanganpenyimpangan yang dilakukan generasi muda tersebut menunjukkan bahwa kurangnya pendidikan akhlak, karakter berbangsa mulia pada saat ini. Akhlak mempunyai kedudukan yang sangat penting dalam kehidupan manusia. Sebab,

${ }^{1}$ Kementerian Pendidikan Nasional, Pengembangan Pendidikan Budaya Dan Karakter Bangsa (Jakarta: Depdiknas, 2010). baik dan buruknya manusia sangat ditentukan oleh akhlaknya. ${ }^{2}$ Oleh karena itu, dalam kehidupan sehari-hari manusia tidak dapat melepaskan diri dari ketentuan-ketentuan yang mengatur atau menilai baik dan buruknya atau benar dan salahnya perbuatan yang mereka kerjakan. Ketentuan tentang baik dan buruknya atau benar dan salahnya suatu perbuatan diperlukan agar kehidupan manusia sehari-hari berjalan dengan baik, karena ada aturan-aturan yang mengikatnya. Dengan demikian akhlak dan manusia merupakan suatu yang menyatu dan tidak dapat dipisahkan selama manusia masih hidup.

Akhlak yang dimiliki oleh manusia bukan merupakan suatu yang dibawa sejak lahir dan bukan pula merupakan suatu yang bersifat tetap, tetapi suatu yang dapat berubah, berkembang dan harus dibentuk melalui proses dan waktu yang cukup lama. Apabila akhlak yang baik sudah terbentuk pada diri seseorang, maka akhlak tersebut harus dijaga dalam kehidupan sehari-hari. Sebab apabila dibiarkan, maka akhlak tersebut akan dapat hilang dari diri seseorang. Oleh karena itu, perlu adanya sebuah upaya untuk tetap menanamkan akhlak yang baik bagi manusia.

Novel ini membahas tentang sikap dan perilaku dalam mengatasi persoalan kemanusiaan. Kemuliaan akhlak dan budi pekerti sudah terlihat jelas. Dari latar belakang di atas, maka permasalahan yang dapat dikaji adalah apa saja nilai-nilai

\footnotetext{
2 M. Furqon Hidayatullah and Muhammad Rohmadi, Pendidikan Karakter: Membangun Peradaban Bangsa (Surakarta: Yuma Pustaka, 2010), 35.
} 
karakter yang terkandung dalam novel Hafalan Shalat Delisa karya Tere Liye.

\section{B. LANDASAN TEORI}

Karya sastra merupakan hasil renungan, baik pengalaman maupun imajinasi pengarang. Seorang pengarang selalu memperhatikan peristiwa hidup dan mencari ide-ide yang sesuai dengan situasi dan kondisi di jamannya. Pengalaman, ide dan gagasan adalah bentuk penerapan pengarang dalam menyesuaikan antara realitas dan karya sastra.

Pada dasarnya karya sastra selalu memberikan kesenangan pada pembaca sebagaimana yang diungkapkan oleh Horance bahwa seni sastra adalah dulce et utile, artinya menyenangkan dan bermanfaat. ${ }^{3}$ Selain menyenangkan, karya sastra juga bermanfaat bagi pembacanya. Sebagai karya sastra yang monumental, novel dapat menggugah semangat dan rasa simpati, empati saat membaca dan merenungkan. Ada nilai-nilai estetika tersendiri yang kadang tidak disadari.

Pendidikan nasional berfungsi mengembangkan kemampuan, membentuk nilai-nilai karakter, dan membentuk peradaban bangsa yang bermatabat dalam rangka mencerdaskan bangsa. Hal ini sejalan denga tujuan pendidikan nasional yaitu agar potensi peserta didik dapat berkembang menjadi manusia yang beriman dan bertakwa. Pendidikan budaya dan karakter bangsa dilakukan melalui pendidikan nilai-nilai atau

${ }^{3}$ Rene Wellek and Austin Warren, Teori Kesusastraan, trans. Melani Budianta (Jakarta: Gramedia Pustaka Utama, 2000), 25. kebajikan yang menjadi nilai dasar budaya dan karakter bangsa. Kebajikan yang menjadi atribut suatu karakter pada dasarnya adalah nilai. ${ }^{4}$ Oleh karena itu pendidikan budaya dan karakter bangsa pada dasarnya adalah pengembangan nilai-nilai yang berasal dari pandangan hidup atau ideologi bangsa Indonesia, agama, budaya, dan nilai-nilai yang terumuskan dalam tujuan pendidikan nasional.

Seseorang yang berkarakter berarti memiliki kualitas mental menyerap nilai-nilai dan keyakinan dengan nilai-nilai yang dikehendaaki masyarakat agar dapaat diimplementasikaan. Pendidikan karakter sangat penting untuk dilaksanakan baik dalam keluarga, masyarakat, sekolah, dan instansi terkait karena bangsa Indonesia telah mengalami kemrosotan mental.

\section{METODE PENELITIAN}

Penelitian ini menggunakan metode analisis kepustakaan dengan pendekatan kualitatif. Analisis ini menitikberatkan pada aspek nilai-nilai karakter yang muncul. Sumber penelitian ini adalah kajian teks yang ada pada novel Hafalan Shalat Delisa karya Tere Liye. ${ }^{5}$

Data penelitian diambil dari novel Hafalan Shalat Delisa karya Tere Liye. Data tersebut dianalisis baik secara intrinsik maupun ekstrinsik dengan pendekataan kualitatif. Kemunculan nilai-nilai karakter pada novel terebut merupakan bagian dari kajian ini.

\footnotetext{
${ }^{4}$ Nasional, Pengembangan Pendidikan Budaya Dan Karakter Bangsa.

5 Tere Liye, Hafalan Shalat Delisa (Penerbit Republika, 2005).
} 
Metode pengumpulan data penelitian ini menggunakan metode pustaka atau dokumen. Metode pustaka diambil teks yang berasal dari novel. Analisis ini dikaji berdasarkan kaitan dengan aspek atau nilai-nilai karakter yang muncul.

Teknik analisis data penelitian ini menggunakan teknik analisis deskriptif dan teknik analisi isi. Teknik analisis deskriptif adalah suatu teknik analisis untuk mendeskripsikan makna data sehingga menimbulkan kejelasan dan mudah dipahami oleh pembaca. ${ }^{6}$ Teknik analisis isi digunakan untuk menganalisis isi komunikasi secara sistematik dan objektif terhadap semua pesan berupa teks, simbol, gambar yang merupakan produk sosial budaya masyarakat setempat.

Dalam penelitian ini metode yang dipakai adalah menggunakan kajian analisis terhadap literatur yang relevan dengan pokok bahasan. Kajian difokuskan pada kepad objek penelitian berupa novel dan bahan-bahan dengan menelusuri nilainilai karakter yang tekandung pada novel Hafalan Shalat Delisa

\section{PEMBAHASAN}

1. Sekilas tentang Novel Hafalan Shalat Delisa

Tere liye merupakan salah satu penulis yang saat ini masih aktif menulis karya sastra berupa novel. Karyakaryanya mengandung sebuah makna yang dapat bermanfaat bagi kehidupan manusia. Melalui novelnya Tere Liye menawarkan berbagai macam nuansa

6 M. Atar Semi, Metode Penelitian Sastra (Angkasa, 1993), 9. kemanusiaan, tentang moral dan keagamaan yang pada dasarnya dapat digunakan sebagai sarana untuk membina akhlak yang baik.

Salah satu karya sastra yang cukup menarik dari karangan Tere Liye adalah novel yang berjudul Hafalan Shalat Delisa. Novel yang berlatar belakang tsunami berkisah tentang keikhlasan dan ketulusan seorang gadis kecil bernama Delisa berumur 6 tahun ketika ia kehilangan harta yang dimilikinya. Ia berusaha mendengarkan hatinya, menyuarakan apa yang dikatakan hatinya. Itulah yang dapat ia lakukan bahkan mengatakan bahwa Tuhan tidak adil karena telah mengambil semua yang ia miliki (ibu, saudara yang dicintainya). Ia sadar hatinya mengatakan tidaklah demikian, sehingga ia mengerti tiada tempat baginya untuk berlindung, meminta bantuan, kecuali pada sebuah kekuatan di luar dirinya yang menguasai segalanya, yakni Allah SWT.

Membaca novel ini seolah-olah pembaca akan terbawa arus. Pembaca berada di suatu tempat kejadian tsunami. Pembaca dihadapkan pada sebuah bencana. Terkadang hati merasa iba, menangis, dan sedih terhadap korbankorban yang tidak berdosa. Pengarang lebih meneteskan air mata saat menuliskan kisah fiksi. Ada rasa empati terhadap korban tsunami di Aceh. Novel ini terinspirasi dan mengisahkan kejadiankejadian bencana alam di Aceh. Walaupun Novel ini fiksi, tetapi ada ketertarikan bencana tsunami dengan cerita-cerita di dalamnya. Pada novel Hafalan Shalat Delisa karya Tere Liye ini banyak mengandung pendidikan akhlak, seperti 
pendidikan akhlak manusia dengan Tuhannya, pendidikan akhlak manusia terhadap diri sendiri, pendidikan akhlak terhadap keluarga dan pendidikan akhlak terhadap sesama manusia. Anak harus mengatakan perkataan yang mulia dan berbuat baik kepada orang tua.

"Dan Tuhanmu Telah
memerintahkan supaya kamu
jangan menyembah selain dia
dan hendaklah kamu berbuat
baik pada ibu bapakmu dengan
sebaik-baiknya. jika salah
seorang di antara keduanya atau
kedua-duanya sampai berumur
lanjut dalam pemeliharaanmu,
Maka sekali-kali janganlah kamu
mengatakan kepada keduanya
perkataan "ah" dan janganlah
kamu membentak mereka dan
ucapkanlah kepada mereka
perkataan yang mulia." (QS. Al-
Isra': 23)

Demikian perintah berakhlak mulia kepada orang tua sudah sangat jelas. Oleh karena itu, sebagai anak wajib mengatakan perkataan yang mulia dan berbuat baik kepada orang tua. Perbuatan ini dilakukan setelah bertakwa kepada Allah SWT. Ajaran tentang pendidikan akhlak yang terdapat dalam novel Hafalan Shalat Delisa ini sangat beraneka ragam. Novel ini mengajarkan kita tentang kemuliaan hidup dan kebaikan antarsesama nmanusia. Media yang digunakan adalah peristiwa bencana tsunami. Melalui bencana ini kita dapat mengahargai, tolong-menoong terhadap sesaman manusia.
2. Sekilas Tokoh dalam Novel Hafalan Shalat Delisa

a) Umi Salamah

Umi Salamah merupakan sosok ibu dari empat anak yang sangat patuh dan beribadah. Kesehariannya ia menjahit pesanan baju tetangga. Hal ini dilakukan untuk mencukupi kebutuhan hidup selama ditinggal suaminya, Abi Usman. Ia sangat menyanyangi anak-anaknya. Ia harus memperlakukan semua anak-anaknya dengan adil. Kurangnya kasih sayang terhadap Abinya, ia tutupi dengan selalu bersama-sama. Ia selalu meluangkan waktu pada anak-anaknya sehingga kedekatan antara ibu dan anak menjadi bagian dari hidup.

\section{b) Fatimah}

Fatimah merupakan anak sulung dari empat bersaudara. Usianya 16 tahun. Fatimah menjadi sosok pengembang tugas di rumah. Ia menggantikan Ummi menjaga adik-adiknya. Fatimah harus menjadi anak yang dewasa dan menjadi teladan untuk adik-adiknya.

c) Aisyah

Aisyah merupakan saudara kembar Zahra. Walaupun kembar, mereka seperti bumi dan langit. Aisyah sangat jahil terhadap saudaranya, terlebih pada Delisa. Segala tindakan dan perkatannya selalu membuat jengkel. Walaupun Aisyah berkarakter seperti itu, Ia anak yang baik dan penurut.

d) Zahra

Zahra merupakan saudara kembar Aisyah. Lain halnya dengan saudaranya. 
Zahra sangat pendiam sampai tidak beruara jika tidak diminta. Karakter seperti itu membuat saura-saudaranya heran. Walaupun Zahra pendiam, Ia tetap anak yang baik dan penurut.

\section{e) Delisa}

Delisa adalah anak bungsu. Usianya baru 5 tahun. Berbeda dengan kakak-kakaknya. Ia mempunyai hobi bermain bola seperti anak laki-laki. Wajahnya sangat menggemaskan. Ia sangaat cerdas dan selalu banyak bertanya. Ia mempunyai pola pikir yang berbeda dengan anak seumurnya.

\section{f) Abi Usman}

Sebagai kepala rumah tangga, Abi Usman sangat bahagia. Ia dikaruniai empat anak gadis yang sangat sholehah. Abi Usman bekerja di perusahaan minyak Internasional. Setiap tiga bulan ia baru pulang. Hari-hari yang panjang untuk keluarga dapat dilakukan Abi Usman saat bulan Ramadhan tiba. Ia dapat mengambil cuti panjang

\section{Nilai-nilai Karakter dalam Novel} Hafalan Shalat Delisa

Novel Hafalan Shalat Delisa merupakan novel yang mengisahkan tentang latar belakang bencana alam tsunami di sekitar Aceh. Tokoh utama Delisa turut menjadi korban saat menyelesaikan ujian hafalan sholatnya. Di pertengahan hafalan tersebut, tiba-tiba air meluluhlantahkan semua yang ada disekitarnya. Novel tersebut banyak memberikan semangat dan motivasi. Setelah membaca novel ini, ada nilai karakter yang dapat diambil dan diteladani. Kekhusu'an ibadah praktik shalat Delisa memberikan pelajaran berharga. Bencana tsunami tidak akan menggagalkan kekhusu'an ibadah praktik shalat Delisa. Nilai-nilai karakter yang dimunculkan memberikan dampak positif terhadap antusias pembaca.

\section{a) religius}

Religius merupakan sikap dan perilaku yang patuh dalam menjalankan ajaran agama yang dianut. Kekuatan untuk selalu berbuat kebaikan dengan shalat berjamaah dan mengaji. Hal ini dapat ditunjukkan pada data berikut.

Ummi sedang mengaji; mengajari Cut Aisyah dan cut Zahra. Sedangkan Fatimah membaca Al Qur'an sendiri. Tidak lagi diajari Ummi. Kak Fatimah bahkan setahun terakhir sudah khatam dua kali. Ini jadwal rutin mereka setiap habis Shubuh. Belajar ngaji dengan Ummi, meskipun juga belajar ngaji TPA dengan Ustadz rahman di Meunasah.

Delisa sedang memegang Jus'amma-nya. Terbatah-batah mengeja alif-patah-a; Ia masih banyak menguap. Terskantukkantuk menunggu giliran menghadap Ummi. Menyetor bacaan yang sedng diejanya pelan-pelan.

\section{HSD:5}

Data tersebut menunjukkan bahwa kedekatan dan keharmonisan keluarga Umi Salamah. Umi Salamah berkewajiban untuk membimbing anakanaknya belajar shalat dan mengaji. Mereka selalu menyempatkan untuk 
mengaji dengan anak-anaknya selesai shalat Shubuh. Shalat Subuh dilaksanakan secara berjamaah. Kegiatan tersebut dilakukan secara rutin. Fatimah sebagai anak sulung dapat membantu adikadiknya. Ummi Salamah menanamkan karakter religius kepada anak-anak dengan cara shalat berjamaah dan membca Al-Quran. Ini menjadi kegiatan rutin keluarga mereka.

b) jujur

Jujur merupakan perilaku yang didasarkan pada upaya menjadikan dirinya sebagai orang selalu dapat dipercaya di dalam perkataan, tindakan, maupun pekerjaan. Jujur menjadi modal utama dalam lingkungan keluarga Umi Salama. Hal ini dapat dilihat pada data berikut.

"U-m-m-i..."
"Ya, ada apa, sayang?"
"Delisa... D-e-l-i-sa cinta Ummi....
Delisa c-i-n-t-a Ummi karena
Allah!" Ia pelan sekali
mengatakan itu. Kalah oleh
desau angin pagi Lhok Nga yang
menyelisik kisi-kisi kamar
tengah. Tetapi suara itu
bertenaga. Amat menggetarkan.
Terdengar jelas di telinga kanan
Ummi. Kalimat yang bisa
meruntuhkan tembok hati.

\section{HSD: 53}

Data tersebut menunjukkan sikap polos pada diri seorang anak berrnama Delisa. Sikap ini dilakukan secara sadar dan tulus. Perkataannya muncul pada hati yang tulus. Kejujuran hati tokoh Delisa, gadis 6 tahun, diungkapkan pada diri Ummi Salamah. Rasa sayangnya diungkapkan Delisa pada ummi karena Allah SWT. Mengatakan rasa sayang dan cinta dengan perasaan jujur itu tidaklah mudah. Hal ini dilakukan oleh anak seusia Delisa. Memang di hati kecil sudah terbesik jiwa dan karakter jujur, tetapi kadangkala semakin kita dewasa, perasaan itu selalu saja terhalangi oleh niat-niat jahat. Ada nilai kejujuran yang muncul dan tertanam sejak kecil. Ummi Salamah sebagai ibu Delisa merasa terharu, betapa anak kecil yang tidk tahu apa-apa dapat merasakaan sifat-sifat jujur. Ia mengatakanya dengan polos di depan ibu, dan saudara-saudaranya.

c) toleransi

Toleransi merupakan sikap yang menghargai perbedaan agama, suku, etnis pendapat, sikap, dan tindakan orang lain yang berbeda dari dirinya. Toleransi yang terjadi pada novel ini merupakan toleransi antarumat beragama. Ada etnis tertentu yang berusaha ingin membantu secara sosial pada etnis lainnya. Hal ini dapat dilihat pada data berikut.

"Jangan Koh. Saya jadi tidak enak... Dulu waktu Fatimah beli Koh Acan juga hanya mau bayar separuh, waktu Zahra dan Aisyah beli juga.... Kali ini biarlah Delisa bayar penuh....." "Nggak... Haiya, saya nggak mungkn pasang harga mahal kalau buat hadiah hafalan shalat! Nggak mungkinlah...." Koh Acan memperbaiki dupa di atas meja panjangnya, tersenyum 
menyakinkan. Koh Acan 100\% Konghucu.

"Kata Abi Usman dulu, shalat itu kan untuk amm-mar mak-rup na-khimhung-khar" Koh Acan kesulitan mengeja ujung kalimatnya.

HSD:20

Data tersebut menunjukkan sikap toleransi yang terlihat pada hati seorang Konghucu bernama Koh Acan. Seorang pengikut agamaa nonmuslim merasakan keharmonisan di kota Lhok Nga. Ada sikap dan rasa saling menghormati terhadap pemeluk agama Islam. Koh Acan adalah penjual kalung.. Sikap toleransi antarumat beragama yang ditanamkan pada Koh Acan adalah bentuk rasa saling menghormati. Hal ini dibuktikan dengan memasang tarif separuh harga kalung yang dibeli Ummi Salamah sebagai hadiah hafalan shalat. Koh Acah sangat senang jika banyak pemuda dapat shalat dengan benar. Jika hal itu dilakukan maka daerah Lhok Nga menjadi tentram. Keragaman agama ini menjadikan rasa toleransi dalam hidup bermasyarakat. Banyak agama di daerah Aceh walaupun mayoitas daerah tersebut beragama Islam. Mereka hidup berdampingan, menghormati antar pemeluknya, dan saling membantu dalam bermasyarakat dan bernegara.

d) disiplin

Disiplin merupakan tindakan yang menunjukkan perilaku tertib dan patuh pada berbagai ketentuan dan peraturan. Nilai kedisipinan tertanam pada kepatuhan untuk mengerjakan shalat tepat waktu secara berjamaah. Hampir dapat dipastikan bahwa keluarga Ummi
Salamah selalu mengerjakan shalat berjamaah tepat waktu. Hal ini dapat ditemukan pada data berikut.

“Delisa mau sekarang yang
berdiri dekat Delisa, Kak Zahra
saja! Atau Kak Fatimah!” Delisa
membujuk Umminya, meminta
perubahan.

HSD:9

Dari data tersebut menunjukkan bentuk-bentuk kedisiplinan keluarga dalam mengerjakan sesuatu. Data tersebut memberikan contoh nilai karakter disiplin dalam mengerjakan shalat. Keluarga Ummi Salamah selalu membiasakan shalat berjamaan tepat waktu. Jika ada salah satu anggota keluarga yang tidak dapat menghafal doa-doa shalat, maka ada yang membantu dengaan menyuarakan agar terdengar. Delisa adalaah anak bungsu yang masih belajar doa-doa shalat. Ia berusaha menghafalnya. Ia butuh diperhatikan oleh kakak-kakaknya.

e) mandiri

Mandiri merupakan sikap dan perilaku yang tidak mudah bergantung pada orang lain dalam menyelesaikan tugas-tugasnya. Nilai kemandirian ini muncul setelah terjadi musibah Tsunami. Banyak penduduk yang kehilangan tempat tinggal. Mereka harus berbenah diri,, mandiri, dan tidak bergantung pada orang lain seterusnya. Hal ini dapat dilihat pada data berikut.

Selama enam minggu kemudian Abi memutuskan untuk membangun kembali rumah 
mereka. Dengan bahan bangunan apa adanya.Hanya berdinding batu bata tanpa diplester, beratap seng bekas reruntuhan, dan berlantai keramik mereka yang lama. Abi dibantu Sersan ahmed dan pasukaannya, serta penduduk Lhok Nga setempat mengerjakan rumah tersebut seharian .

\section{HSD:171}

Dari data tersebut salah satu tokoh bernama Abi Usman, salah satu warga Aceh yang terkena bencana, kehilangan harta benda walaupun ia saat kejadiaan tidak berada di Aceh. Abi Usman berada di luar kota. Ia kehilangan rumah, istri dan anak-anaknya. Ia hanya mempunyai putri satu-satuya bernama Delisa.

Abi Usman ingin mandiri dengan mendirikan rumah seadanva dari sisa-sisa bencana. Ia tidak ingin berada terusmenerus di posko bantuan. Dengan mantuan warga sekitar, Abi Usman dapat mewujudkan impian mendirikan rumah lagi walauun tidak seperti sebelum bencana Tsunami. Ada nilai-nilai kemandirian tersendiri terhadap keluarga korban Tsunami yang selamat untuk bangkit lagi. Ini bagian dari sikap optimis untuk mandiri setelah bencana.

f) rasa ingin tahu

Rasa ingin tahu merupakan sikap dan tindakan yang berupaya untuk mengetahui lebih mendalam dan meluas dari sesuatu yang dipelajari, dilihat, dan didengar. Sikap ketekunan dan rasa ingin tahu terhadap sesuatu yang baru bagi Delisa adalah hal yang wajib. Hal ini dapat dilihat pada data berikut.

Bagaimana pula adiknya akan
tahu teknik menghafal seperti
itu? Mati berarti mati; yaya
berarti hidup. Delisa mana tahu
artinya. Delisa baca arabnva saja
ribet minta ampun-belum bisa;
baru belajar.
Tetapi Delisa diam saja.
Memikirkan olok-olok Kak
Aisyah barusan

“ In-na sha-la-ti, wa-nu-su-ki, wa-maa... wa-ma mah-ya-ya... wa-ma ma-ti..."

Hore! Lancar. Delisa nyengir senang.

"Makasih ya, Kak!" Delisa berseru kepada kakaknya.

\section{HSD:13-14}

Dari data tersebut sikap optimis terhadap berbagai persoalan. Delisa hampir setiap hari rajin menghafal bacaan shalatnya. Ia ingin menyelesaiakan dengan mudah saat tes hafalan shalat. Sikap rasa ingin tahu yang dilakukan Delisa adalah saat tertukarnya hafalan shalat. Antara makna mati dahulu atau hidup dahulu. "Inna sha-la-ti, wa-nu-su-ki, wa-maa... wa-ma mah-ya-ya... wa-ma ma-ti...". Walaupun Delisa masih bingung bahasa Arabnya, ia tidak putus asa. Ia tetap berusaha sampai berhasil. Sambil berpikir Ia pun bisa memutuskan mana yang lebih dahulu diucapkan. 
g) semangat kebangsaan

Semangat kebangsaan merupakan cara berpikir, bertindak, dan berwawasan yang menempatkan kepentingan bangsa di atas kepentingan diri dan kelompok. Bangsa Indonesia merasa terpukul ketika melihat berita tsunami melanda kawasan barat Indonesia. Ada semacam rasa simpati bahkan empati. Perasaan itu juga muncul pada diri manusia yang melihat perkembangan bencana tsunami. Sikap ini juga direspon oleh pejabat tinggi bangsa Indonesia. Hal ini dapat dilihat pada data berikut.

SBY-JK tergesa memasuki ruang rapat istana.

Rapat kabinet super-mendadak. "ini masalah serius! Kita harus melakukan banyak hal..." serentak semua Menteri memasang wajah serius.

\section{HSD:88}

Dari data tersebut menunjukkan ada kepedulian serius pemerintah dalam mengatasi persoalan bencana tsunami. Semangat kebangsaan terlihat pada data yang menunjukkan kepedulian pejabat tinggi setingkat presiden dan menteri. Mereka langsung menggelar rapat mendadak. Kepentingaan pribadi dan golongan harus dikesampingkan. Bencana tsunami adalah bencana kemanusiaan. Negara butuh bantuan secepatnya. Mereka mengambil langkah-langkah strategis demi menyelamatkan umat manusia. Kebijaakan pemerintah ini membawa dampak bagi dunia. Mereka turut andil dalam menyelesaikan bencana alam. Apapun yang dapat dilakukannya harus dilakukan secara ikhlas demi bangsa dan sikap rasa tolong-menolong.

h) menghargai prestasi

Menghargai prestasi merupakan sikap dan tindakan yang mendorong dirinya untuk menghasilkan sesuatu yang berguna bagi masyarakat, mengakui, dan menghormati orang lain. Bentuk kepedulian ibu dalam membimbing anaknya terkait dengan ajaran-ajaran shalat dan cara menghafal doa-doa shalat. Sikap ini dilakukan oleh Ummi Salamah terhadap anaknya Delisa.. Hal ini dapat dilihat pada data berikut.

"Bukan, Sayang.... Kan kita sudah janji, kamu ngak akan pegang kalungnya sebelum kamu hafal seluruh bacaan shalat! Sebelum lulus dri ujian Bu Guru Bur." Ummi berkata tegas.

HSD:22

Dari data tersebut keteguhan hati Ummi Salamah terhadap Delisa. Ada suatu bentuk penghargaan yang diberikan seorang ibu terhadap anaknya atas prestasi. Delisa akan memakai kalung pesanan dengan huruf D sebagai hadiah hafalan shalatnya. Bentuk penghargaan prestasi memberikan sikap bagi Delisa untuk semangat menghafal bacaan shalat. Kadangkala pikiran Delisa selalu tertuju pada sebuah kalung. Ummi Salamah harus senantiasa menasihati Delisan. Ia seringkali berbicara kepada Delisa bahwa janganlah engkau melihat nilai hadiahnya, tetapi keikhlasan dalam menghafal bacaan shalat. Hadiah bukanlah akhir dari suatu keberhasilan. 
i) cinta damai

Cinta damai merupakan sikap, perkataan, dan tindakan yang menyebabkan orang lain merasa senang dan aman atas kehadiran dirinya. Rasa senang harus dirasakan Delisa karena ia baru saja terkena bencana. Kakinya lumpuh, selalu mengingat saudarasaudaranya terutama Ummi. Rasa sedih pun mulai reda dengan kehadira suster Shopi.

Delisa saat itu sedang bermain bersama Suster Shopi, duduk bersandar di ranjangnya. Memegang dua boneka teddy bear, sekarang diberi pita biru. ... Shopi hanya tersenyum melihat gadi kecil di hadapannya begitu riang bercerita dengan bahasanya. Bermain bonekabonekaan.

HSD:143

Dari data tersebut menunjukkan betapa senang dan gembira atas kedatangan suster Shopi. Ia berusaha menghibur Delisa. Suster Shopi memberikan boneka teddy bear kepada Delisa. Boneka tersebut sebagai teman bermain, bahkan dianggap sebagai saudara Delisa. Delisa tinggal sebatang kara. Ia ditinggal saudara-saudaranya terutama Ummi Salamah. Sementara Abi Usman masih berusaha mencari Delisa. Rumah sakit darurat yang dibuat untuk korban tsunami menjadi tempat sementara yang menyenangkan. Delisa masih ditinggal di rumah sakit sampai Abi Usman menjemputnya. j) gemar membaca

Gemar membaca merupakan kebiasaan menyempatkan waktu untuk membaca berbagai bacaan yang memberikan kebajikan bagi dirinya. Pada novel ini Delisa tidak henti-hentinya menghafal doa shalat untuk ujian dikemudian hari. Ia terus menghafal setiap hari. Waktu yang dipergunakan hanya membaawa buku-buku bacaan untuk hafalan shalat. Hal ini dapat dilihat pada data berikut.

"Sub-haa-na-rab-bi-yal a'-la wa...waa... bihamdih!"

"Aduh itu kan bacaan buat sujud, Delisa!" Fatimah yang juga sedang belajar bersama-sama menoleh.

Delisa mengulang lagi menghafal dari bacaan surat pendek. Takbir. Kemudian bacaan ruku' lagi.

"Sub-haa-na-rab-bi-yal-a... a... a'la wa-bi-ham-dhi!" Ups. Ketukar lagi, kan?

Delisa nyengir. Fatimah menatapnya sambil tersenyum tipis.

HSD:24

Dari data tersebut menunjukkan tokoh yang bernama Delisa selalu menyempatkan membaca buku bacaan shalatnya. Ia senantiasa membawa dan menghafalkannya. Teguran dan ejekan dari kakaknya tidak menyurutkan minat untuk membaca doa hafalan shalatnya. Ada semangat pada diri Delisa untuk menyelesaikan hafalan shalat pada saat tes 
berlangsung. Di samping itu, motivasi Umi Salamah memberikan hadiah berupa kalung membuat Delisah tidak hentihentinya tetap membaca dan belajar menghafal doa shalat. Sikap gemar membaca inilah yang harus ditiru agar tidak lupa saat ujian berangsung.

k) peduli lingkungan

Peduli Lingkungan merupakan sikap dan tindakan yang selalu berupaya mencegah kerusakan pada lingkungan alam sekitarnya dan mengembangkan upaya-upaya untuk memperbaiki kerusakan alam yang sudah terjadi. Setelah Acah dilanda tsunami berkepanjangan, maka terihat banyak sekali korban berjatuhan. Hal ini dapat dilihat pada data berikut.

Sore itu mereka mengumpulkan ratusan tubuh. Sayangnya tak ada satupun yang ditemukan masih bernafas. Tidak ada. Bagaimana mungkin keajaiban itu ada? Lhok Nga hampir 80\% musnah. Kalaupun ada yang selamat, karena memang sedang beruntung berada di manalah.

\section{HSD:101}

Data tersebut menunjukkan kepedulian terhadap lingkungan yang terkena bencana tsunami. Indonesia bagian barat terutama Aceh tanpa disadari terkena bencana Tsunami. Bencana tersebut seperti halnya bencana-bencana lainnya. Rasa kepedulian yang teramat dalam ditunjukkan kepada dunia. Rasa simpati terutama empati menjadi sangat akrab. Kepedualian sosial masyarakat sekitar melihat bencana tsunami langsung. Mereka tidak mengenal darimana berasal. Suku, bangsa, dan bahasa tidak menjadi penghalang. Siapa saja datang menolong para korban. Kepedulian terhadap lingkungan sudah tertanam pada jiwa manusia yang peka, selalu bersimpati, dan berempati terhadap kerusakan lingkungan. Korban berjatuhan tanpa memperdulikan status, usia bahkan jabatan.

Dia tahu, semua pemandangan kemarin sungguh menggetarkan. Semua kota yang luluh lantah itu sepuluh kali lebih menekan dibandingkan pertempuran mereka selama ini. Mayat-mayat yang bergelimpangan, tanpa lengan, tanpa tangan, dan lain sebagainya seratus kali lebih menakutkan dibandingkan mayat-mayat korban muntahan peluru senjata mereka selama ini.

\section{HSD:105}

Data tersebut menunjukkan gambaran kota sekitar Aceh yang sudah diluluhlantahkan bencana tsunami. Bencana itu tidak mengenal apa dan siapa saja. Kondisi kota hancur hanya tersisa sebuah masjid. Korban berjatuhan. Kota Aceh ibarat kota mati. Hampir tidak ada kehidupan pascaterjadi bencana. Kejadian saat bencana tsunami lebih besar jika dibandigkan dengan beberapa peperangan yang selama ini terjadi. Begitu dahsyatnya bencana tsunami tersebut. Ada upaya penelamatan terhadap para korban. Rasa 
simpati dan empati kita diuji. Kita sebagai insan manusia mulai tergerak hati. Ada sikap dan karakter yang muncul secara tidak sadar. Aku ingin menolong, aku ingin menolong. Mungin kata-kata itu terbesit dalam jiwa insan manusia yang melihat kejadian di Aceh.

\section{l) peduli sosial}

Peduli Sosial merupakan sikap dan tindakan yang selalu ingin memberi bantuan pada orang lain dan masyarakat yang membutuhkan. Ada banyak lembaga sosial yang menampung bantuan-banuan kemanusiaan untuk korban bencana tsunami. Semua manusia mengetahui dengan jelas bencana tsunami karena informasi begitu cepat. Rasa simpati dan empati, belasungkawa selalu mengalir tanpa henti. Hal ini dapat dilihat pada data berikut.

Pagi ini sebelum mereka memulai pelajaran kelas satu Elementary School, Michelle dan Maragaretha berdiri di depan kelas. Memimpin doa teman temannya. Berkata lemah.... "Untuk teman-teman kami di Aceh... Untuk teman-teman kami di Indonesia... semoga Tuhan selalu menyertai kalian...."

\section{HSD:86}

Dari data tersebut menunjukkan kepedulian manusia terhadap manusia lain yang telah terkena bencana alam. Ruang dan waktu tidaklah menjadi penghambat. Sebagai contoh tokoh Michelle dn Margaratetha adalah segelintir atau wakil dari siswa-siswi yang sedang belajar diblahan dunia. Merek telah mendengar seolah-olah dekat padahal jarak pemisah adalah lauan dan benua. Kepedulian terhadap bencana adalah bentuk rasa persaudaraan yang dilandari jiwa kemanusiaan.

Ibu Guru Ani tersenyum mengeluarkan selembar kertas dari amplop, lantas mulai membaca. " .... Sehari setelah melihat berita itu, kami mengumpulkan uang saku masing-masing. Ibu Guru yang mengumpulkannya. Lantas mengirimkannya. Lewat transfer bank ke lembaga sosial. Semoga itu membantu teman-teman. ... Salam hangat dari kami. Teman Jauh kalian. Michelle-Margareth, dan anak-anak kelas 1 Elementary School Ros The Elizabeth. Londin Inggris."

HSD:204-205

Dari data tersebut menunjukkan rasa kepedulian siswa-siswa dari daratan Eropa. Mereka berkirim surat pada temanteman seusia di wilaah Acah. Guru Ani membacakan secarik kertas yang bertuliskan rasa simpati dan empati. Mereka di belahan dunia sudah mengetahui kejadian bencana tsunami. Sikap dan kepedulian sosial dibuktikan dengan mengumpulkan sebagian uang saku dan mentransferkan ke Bank tempat lembaga sosial. Ada perasaan was-was dan prihatian. Dalam jiwa mereka rasa empati yang tertanam adalah jika hal ini terjadi di daerah saya, maka apa yang harus aku lakukan. Itulah landasan berpijak mereka 
untuk merasa saling berbagi terhadap korban tsunami di sekitar wilayah Aceh. m) tanggung jawab

Tanggung jawab merupakan sikap dan perilaku seseorang untuk melaksanakan tugas dan kewajiban yang seharusnya dilakukan baik terhadap diri sendiri, masyarakat, maupun lingkungan. Hal ini dapat dilihat pada data berikut.

Terus bergerak mengerikan, mendekat ke sekolah Delisa. Menyebar hawa mati tak terkira. "sa-mi'al-laa-hu-li-man-ha-midah...."

Gelombang itu menyentuh tembok sekolah

"Rab-ba-na-la-kal-ham-du......"

Tubuh Delisa terpelanting. Gelombang tsunami sempurna sudah membungkusnya. Delisa megap-megap.

Delisa terus memaksakan diri, membaca takbir setelah i'tidal...."Al-la-hu-ak-bar..."

Delisa harus terus membacanya! Delisa tidak peduli tembok yang siap menghancurkan kepaalanya.

\section{HSD:71}

Data tersebut menunjukan nilai karakter rasa tanggung jawab pada diri seorang anak. Tanggung jawab Delisa adalah menyelesaikan hafalan shalatnya walaupun ada kejadian yang menimpa di sekelilingnya. Bentuk rasa tanggung jawab yang dimiliki Delisa benar-benar muncul dalam diri seorang gadis kecil. Ia ingin menampakkan jati diri bahwa Delisa mampu menjalankan semua vang akan menjadi tanggung jawabnya. Ia berusaha khusu' seperti yang diutarakan ustadz Rahman. Kekhusu'an inilah membuat Delisa tidak tahu bahwa bencana luapan air menghantam dirinya. Ia tidak tahu ada bencana tsunami. Walaupun ada sesuatu yang menggoda dan bencana yang mengancam, Delisa harus fokus. Ia harus menyelesaikan tugasnya menyelesaikan hafalan shaalat. Tsunami yang sudah mulai berjalan tidak membuat surut karena rasa tanggung jawab sudah tertanam pada diri Delisa. Delisa harus menyelesaikan hafalan shalatnya.

\section{E. PENUTUP}

Berdasarkan pembahasan pada analisis novel Hafalan Shalat Delisa dapat disimpulkaan bahwa pembaca dapat menemukan beberapa kemunculan nilai karakter pada novel tersebut. Nilai karakter tersebut antara lain adalah sikap nilai religius, jujur, toleransi, disiplin, mandiri, rasa ingin tahu, semnagat kebangsaan, menghargai prestasi, cinta damai, gemar membaca, peduli ingkungan, peduli sosial, dan tanggung jawab. Nilainilai tersebut harus tercermin dalam pola bertingkah lagu dalam masyarakat. Nilainilai tersebut ditampilkan untuk memberikan pelajaran bagi pembaca dalam menentukan sikap hidup.

Kisah pada novel ini adalah kisah fiktif yang berlatar belakang bencana alam. Pembaca dapat melihat dan merasakan kejadian tersebut. Ada kepedulian dan sikap simpati maupun empati dari kejadian-kejadian bencana 
tsunami Aceh dalam novel ini. Dari beberapa nilai yang terlihat, pembaca dapat menerapkan dan mengambil hikmah dan manfaat dari kejadiaan.

\section{F. DAFTAR PUSTAKA}

Hidayatullah, M. Furqon, and Muhammad Rohmadi. Pendidikan Karakter: Membangun Peradaban Bangsa. Surakarta: Yuma Pustaka, 2010.

Liye, Tere. Hafalan Shalat Delisa. Penerbit Republika, 2005.

Nasional, Kementerian Pendidikan. Pengembangan Pendidikan Budaya Dan Karakter Bangsa. Jakarta:

Depdiknas, 2010.

Semi, M. Atar. Metode Penelitian Sastra. Angkasa, 1993.

Wellek, Rene, and Austin Warren. Teori Kesusastraan. Translated by Melani Budianta. Jakarta: Gramedia Pustaka Utama, 2000. 